\begin{tabular}{|c|c|c|c|}
\hline $\begin{array}{l}\text { Case Reports in } \\
\text { Oncolous }\end{array}$ & $\begin{array}{l}\text { Case Rep Oncol 2010;3:310-314 } \\
\text { DOI: } 10.1159 / 000320740\end{array}$ & $\begin{array}{l}\text { Published online: } \\
\text { September 9, } 2010\end{array}$ & $\begin{array}{l}\text { (2) } 2010 \text { S. Karger AG, Basel } \\
\text { ISSN } 1662-6575 \\
\text { www.karger.com/cro }\end{array}$ \\
\hline
\end{tabular}

\title{
Extraordinarily Prolonged Disease Recurrence in a Granulosa Cell Tumor Patient
}

\author{
Lisa N. Abaid Monica Mosquera-Caro $^{\mathrm{b}}$ Rita C. Kankus ${ }^{a}$ \\ Bram H. Goldstein ${ }^{a}$ \\ ${ }^{a}$ Gynecologic Oncology Associates, Hoag Cancer Center, ${ }^{b}$ Department of \\ Pathology, Hoag Memorial Hospital Presbyterian, and 'Department of Radiology, \\ Hoag Memorial Hospital, Newport Beach, Calif., USA
}

\section{Key Words}

Granulosa cell tumor - Sex cord stromal tumors · Diagnosis · Treatment

\begin{abstract}
Background: Granulosa cell tumors are rare sex cord stromal lesions that comprise approximately $3 \%$ of all ovarian neoplasms. The vast majority of granulosa cell tumors are considered indolent but in spite of aggressive management, delayed recurrence is of significant concern.

Case Report: We describe a case involving a 67-year-old woman who presented with abdominal pain, bloody stools, and mild nausea. Following a CT scan of the abdomen and pelvis, a $19-\mathrm{cm}$ pelvic mass was identified. Her prior medical history included a hysterectomy for uterine fibroids 40 years ago and a bilateral salpingo-oophorectomy for a presumed granulosa cell tumor 20 years ago. Final pathology revealed granulosa cell tumor with small bowel mesentery involvement. The patient underwent surgical resection and adjuvant chemotherapy; she is currently doing well.

Conclusion: Granulosa cell tumors are considered to be of low malignant potential but they have the capacity to recur, even several years following initial patient management. This case exemplifies the disease's capacity for prolonged recurrence and further accentuates the significance of long-term follow-up in these patients.
\end{abstract}

\section{Introduction}

Sex cord stromal tumors are relatively uncommon lesions that develop from the gonadal stroma. They constitute nearly $5-7 \%$ of all ovarian lesions and include granulosa stromal tumors, fibroma-thecoma, Sertoli-stromal cell tumors and steroid cell tumors [1, 2]. Granulosa cell tumors are particularly rare, accounting for $2-3 \%$ of all ovarian malignancies [2]. 
Granulosa cell tumors have typically high survival rates, but they can be associated with extremely prolonged disease progression intervals; reported studies have described recurrences several years following initial treatment [3-5]. We report herein the history of a granulosa cell tumor patient who presumably exhibited recurrent disease 20 years following her oophorectomy for a hitherto, unrecognized granulosa cell tumor.

\section{Case Report}

A 67-year-old (gravida 4, para 4) woman complained of persistent lower abdominal pain and mild nausea in December 2009. She had been having bloody stools for several months with symptomatic anemia requiring blood transfusion prior to her referral to our practice. A palpable mass was found on exam and a CT scan of the abdomen and pelvis demonstrated a $17 \times 19 \times 13 \mathrm{~cm}$ pelvic mass, extending into the midline and right pelvis. There were also some solid, cystic components and a calcified center. Laboratory work-up revealed a CA-125 of $155 \mathrm{U} / \mathrm{ml}$, a CEA of $2.2 \mathrm{ng} / \mathrm{ml}$ and serum inhibin B levels of $1,394 \mathrm{pg} / \mathrm{ml}$. The patient's prior medical history was significant for hypertension, mild diabetes, herniorrhaphy in 2000 and 1987, an appendectomy and bilateral salpingo-oophorectomy in 1987 for a probable granulosa cell tumor, and total abdominal hysterectomy in 1969 for uterine fibroids.

Colonoscopy and esophagogastroduodenoscopy procedures were then conducted, neither of which identified an intra-luminal colonic or gastric mass. Nevertheless, on the colonoscopy, there was some blood originating from the terminal ileum and small bowel. The differential diagnoses included primarily tumors of gastrointestinal origin such as GIST type tumor, retroperitoneal sarcoma or lymphoma. However, a CT-guided biopsy excluded lymphoma and stains were positive for inhibin, indicating a gynecologic neoplasm.

At laparotomy, some cloudy ascites were encountered and the primary mass was found to originate from the mesentery of the ileum. There were tumor nodules studding the mesentery and peritoneum, primarily along the gutters and in the pelvis. At the root of the mesentery, the vasculature supplying the dominant mass was quite extensive. The bowel was divided proximally and distally to the mass and the involved mesentery was also resected en bloc (fig. 1).

The remaining tumor nodules were removed via a combination of sharp dissection and cautery. Further, they were stripped out from the pelvis and bilaterally along the pelvic sidewall. The patient's appendix, uterus, cervix, tubes and ovaries were surgically absent. There were some additional omental nodules identified and, thus, an infracolic omentectomy was performed.

Final pathology revealed a malignant granulosa cell tumor involving the small bowel mesentery and ileum (fig. 2). Moreover, there were scattered tumor nodules identified within the mesentery, small bowel and omentum. Initially, a chemotherapy regimen comprising bleomycin, etoposide and platinum was considered, but because the patient had cardiac complications, she began 6 cycles of paclitaxel (175 $\mathrm{mg} / \mathrm{m}^{2}$ ) and carboplatin (AUC $=6$ ) in January 2010. In June 2010, her serum inhibin B levels declined to $<10 \mathrm{pg} / \mathrm{ml}$. Currently, she is doing well and receiving routine follow-up from her gynecologic oncologist.

\section{Conclusion}

Granulosa cell tumors are estrogenic ovarian tumors that have a propensity to develop in postmenopausal women [1]. Patients often present with intra-abdominal bleeding, abdominal distension or pain due to the tumor's potentially considerable size. Moreover, $50-60 \%$ of patients will develop either endometrial hyperplasia or a concurrent uterine cancer [3].

The majority of granulosa cell tumors are considered to be of low malignant potential. Disease stage appears to be the most important prognostic factor; most patients present with stage I tumors that coincide with 5 -year survival rates $(>90 \%)$, similar to borderline 
ovarian tumors [1]. Conversely, large tumor size $(>10 \mathrm{~cm})$, high mitotic index and lymphatic invasion are associated with disease recurrence and a poor outcome $[2,6]$.

There are sufficient data to substantiate the risk for prolonged (e.g., up to 10 years) recurrence rates with granulosa cell tumors [2] and, in rare exceptions, extraordinarily protracted time frames [3-5]. Hasiakos et al. [3] described a granulosa cell tumor patient who had surgery alone and developed disease recurrence 25 years following the initial diagnosis. Moreover, Hines et al. [4] reported on a granulosa cell tumor patient who was treated with surgery and adjuvant bleomycin, etoposide and cisplatin chemotherapy; she exhibited progressive disease 37 years later.

In the current study, our patient underwent a bilateral salpingo-oophorectomy in 1987 for a probable granulosa cell tumor, eventually developing progressive disease in 2009 . We suspect that the disease's recurrence in the gastrointestinal tract may be attributed to transcoelomic spread, a process which has been implicated in ovarian and colonic malignancies $[1,7]$. However, we recognize that without the pathology from the original surgical procedure, we cannot confirm that there is indeed a disease recurrence. One may also conjecture that the granulosa cell tumor developed from remaining fragments of ovarian tissue in situ subsequent to the patient's bilateral salpingo-oophorectomy in 1987.

Conservative surgery is the recommended treatment for granulosa cell tumors in patients who wish to retain their fertility status. In particular, a unilateral salpingooophorectomy, staging and an endometrial biopsy to exclude uterine cancer may be adequate for stage I disease $[1,2]$. Alternatively, in patients with more advanced stage disease, or when reproductive status is immaterial, standard management comprises total abdominal hysterectomy, bilateral salpingo-oophorectomy and surgical debulking. Chemotherapy consisting of bleomycin, etoposide and cisplatin has been extensively employed; more recently, taxanes in combination with platinum therapy have been evaluated to mitigate toxicity and improve progression-free survival rates $[1,3,8]$.

Since long-term surveillance is essential for granulosa cell tumor patient management, tumor markers have been considered. Serum estradiol levels have not proven to be reliable, but elevated serum inhibin appears to correspond with increased granulosa cell tumor size $[3,9]$. Elevated serum inhibin, a peptide hormone normally produced by ovarian granulosa cells, potentially coincides with increased granulosa cell tumor size [10].

Inhibin A and B are both significantly involved in pituitary follicle-stimulating hormone (FSH) secretion. However, inhibin A is primarily secreted by the corpus luteum and is associated with regulating FSH secretion during luteal-follicular transition; inhibin $\mathrm{B}$ is secreted in response to FSH and is a sensitive marker for follicular growth [9]. Clinically, a dramatic increase in serum inhibin B levels has been reported in granulosa cell tumor patients, whereas with serum inhibin A, the levels were far less pronounced [10]. Consequently, serial inhibin B measurement may be considered as a diagnostic marker for primary and recurrent disease.

\section{Acknowledgment}

This study was supported by a grant from the Women's Cancer Research Foundation. 


\begin{tabular}{|c|c|c|c|}
\hline $\begin{array}{l}\text { Case Reports in } \\
\text { Orcolocy }\end{array}$ & \begin{tabular}{|l} 
Case Rep Oncol 2010;3:310-314 \\
DOI: $10.1159 / 000320740$
\end{tabular} & $\begin{array}{l}\text { Published online: } \\
\text { September } 9,2010\end{array}$ & $\begin{array}{l}\text { O 2010 S. Karger AG, Basel } \\
\text { ISSN 1662-6575 } \\
\text { www.karger.com/cro }\end{array}$ \\
\hline
\end{tabular}

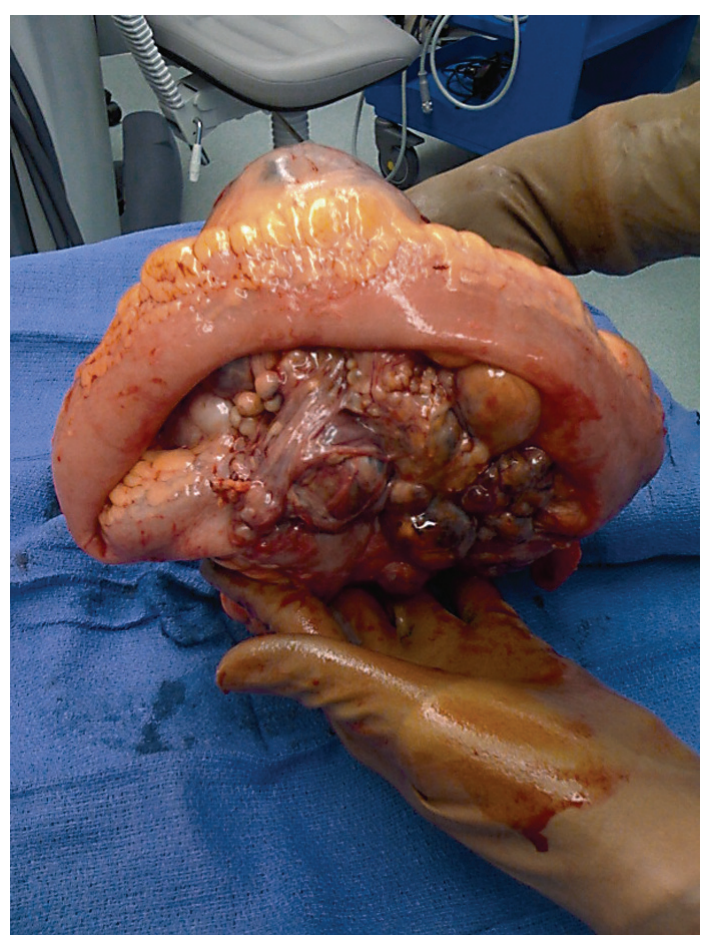

Fig. 1. Gross photograph of the granulosa cell tumor.

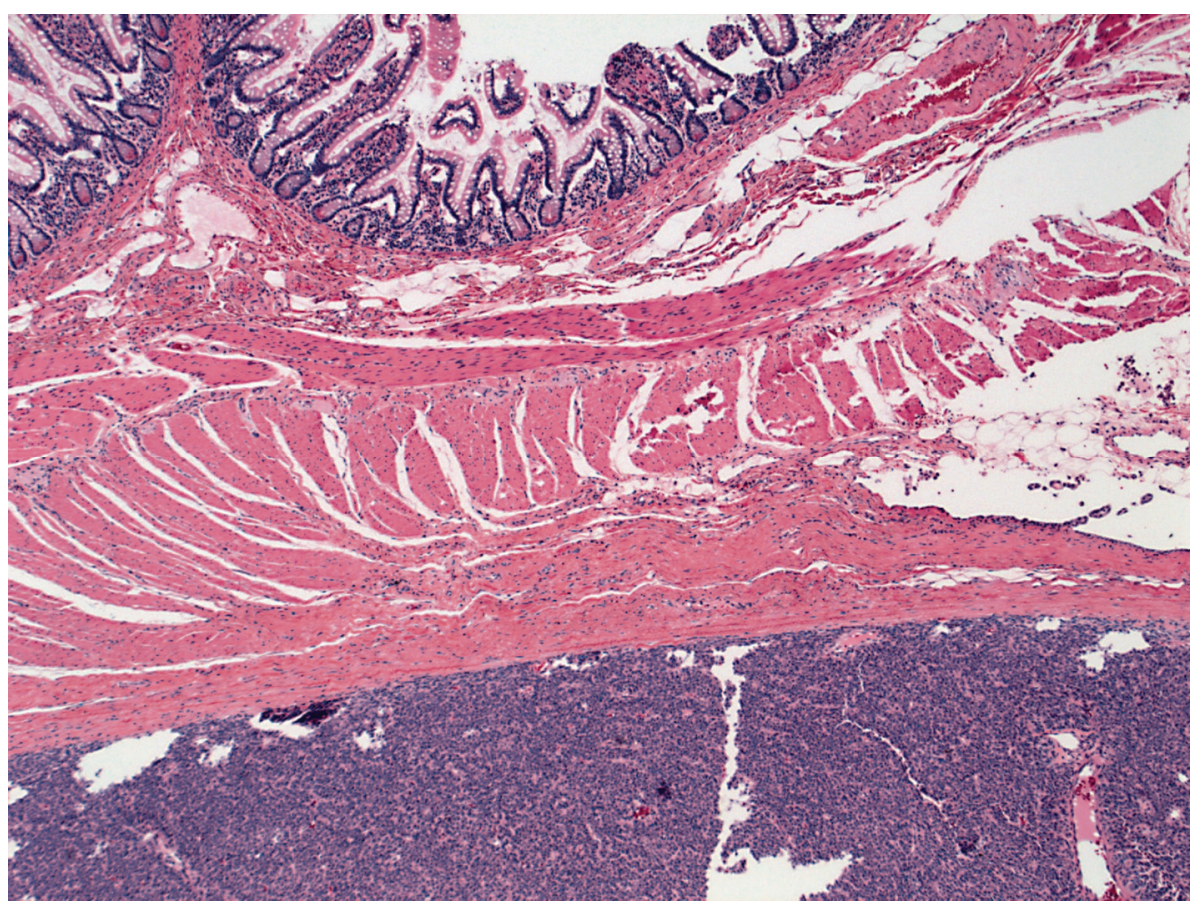

Fig. 2. Section of small-bowel mucosa and submucosal tumor mass (10x). 


\section{References}

1 Duncan TJ, Lee S, Acheson AG, Hammond RH: An ovarian stromal tumor with luteinized cells: an unusual recurrence of an unusual tumor. Int J Gynecol Cancer 2008;18:172-175.

2 Chan JK, Zhang M, Kaleb V, et al: Prognostic factors responsible for survival in sex cord stromal tumors of the ovary - a multivariate analysis. Gynecol Oncol 2005;96:204-209.

- 3 Hasiakos D, Papakonstantinou K, Karvouni E, Fotiou S: Recurrence of granulosa cell tumor 25 years after initial diagnosis. Report of a case and review of the literature. Eur J Gynaecol Oncol 2008;29:86-88.

4 Hines JF, Khalifa MA, Moore JL, Fine KP, Lage JM, Barnes WA: Recurrent granulosa cell tumor of the ovary 37 years after initial diagnosis: a case report and review of the literature. Gynecol Oncol 1996;60:484-488.

5 Singh-Ranger G, Sharp A, Crinnion JN: Recurrence of granulosa cell tumour after thirty years with small bowel obstruction. Int Semin Surg Oncol 2004;1:4.

-6 Uygun K, Aydiner A, Saip P, et al: Granulosa cell tumor of the ovary: retrospective analysis of 45 cases. Am J Clin Oncol 2003;26:517-521.

7 Tan DS, Agarwal R, Kaye SB: Mechanisms of transcoelomic metastasis in ovarian cancer. Lancet Oncol 2006;7:925-934

8 Brown J, Shvartsman HS, Deavers MT, et al: The activity of taxanes compared with bleomycin, etoposide, and cisplatin in the treatment of sex cord-stromal ovarian tumors. Gynecol Oncol 2005;97:489-496.

9 Petraglia P, Luisi S, Pautier P, et al: Inhibin B is the major form of inhibin/activin family secreted by granulosa cell tumors. J Clin Endocrinol Metab 1988;83:1029-1032.

10 Lappohn RE, Burger HG, Bouma J, Bangah M, Krans M, de Bruijn HW: Inhibin as a marker for granulosa-cell tumors. NEJM 1989;321:790-793. 